\title{
Aplikasi Sistem Pakar Untuk Mendiagnosa Gangguan Kepribadian Pada Remaja Dengan Menggunakan Metode Certainty Factor (CF)
}

\author{
Adi Suwarno ${ }^{1}$ Ishak Husin ${ }^{2}$; Ulfi Elana Zenni ${ }^{3}$ \\ ${ }^{1,2,3}$ STMIK Bani saleh \\ ${ }^{1}$ adisuwarno657@gmail.com
}

\begin{abstract}
Adolescence is a period of increased activity, maturity of sexuality, growth of awareness, and recognition that the time free from problems experienced in childhood is lost forever. So they experience emotional instability as a result of adjusting themselves to new patterns of behavior and social environment. Personality and behavior disorders in adolescents are problems faced by parents and their environment. In this study, this knowledge was obtained from experts, namely psychologists. This study uses an interview method with a Psychologist. The expert system is a system designed to assist in detecting diseases with a dynamic knowledge base. This expert system can deduce the user's illness based on the symptoms of adolescent personality disorders that are entered into the system. As for the purpose of the research is to produce an expert system to assist psychologists in documenting their knowledge. The expert system will display the amount of confidence the symptom has on the possibility of the user's illness. The amount of the trust value is the result of calculations using the Certainty Factor (CF) method. The results obtained from this study are the application of an expert system to diagnose adolescent personality disorders with the certainty factor method by using a computer as a tool to access data.
\end{abstract}

Keywords: Teenagers, Adolescent Personality Disorders, Expert System, Certainty Factor

\begin{abstract}
ABSTRAK
Masa remaja adalah masa dimana meningkatnya aktivitas, kematangan seksualitas, pertumbuhan kesadaran, dan pengakuan bahwa masa bebas dari masalah yang dialami pada masa kanak-kanak hilang untuk selamanya. Sehingga mereka mengalami ketidakstabilan emosi sebagai dampak dari penyesuaian diri terhadap pola perilaku dan lingkungan social yang baru. Gangguan kepribadian dan perilaku pada remaja adalah masalah yang dihadapi oleh orang tua dan lingkungannya. Pada penelitian ini, pengetahuan ini didapat dari pakar yaitu psikolog. Penelitian ini menggunakan metode wawancara dengan Psikolog. Sistem pakar merupakan suatu sistem yang dirancang untuk membantu dalam mendeteksi penyakit dengan basis pengetahuan yang dinamis. Sistem pakar ini dapat menyimpulkan penyakit yang diderita user berdasarkan gejala-gejala ganguan kepribadian remaja yang dimasukkan ke dalam sistem. Adapun untuk tujuan penelitian adalah menghasilkan suatu sistem pakar untuk membantu psikolog dalam mendokumentasikan ilmunya. Sistem pakar akan menampilkan besarnya kepercayaan gejala tersebut terhadap kemungkinan penyakit yang diderita pengguna. Besarnya nilai kepercayaan tersebut merupakan hasil perhitungan dengan menggunakan metode Certainty Factor (CF). Hasil yang diperoleh dari penelitian ini adalah Aplikasi sistem pakar untuk mendiagnosa gangguan Kepribadian remaja dengan metode certainty factor dengan memanfaatkan komputer sebagai alat bantu untuk mengakses data.
\end{abstract}

Kata Kunci: Remaja, Gangguan Kepribadian Remaja, Sistem Pakar, Certainty Factor 


\section{KILAT}

Vol. 8, No. 2, Oktober 2019, P-ISSN 2089-1245, E-ISSN 2655-4925

\section{PENDAHLUAN}

\subsection{Latarbelakang masalah}

Dengan kemajuan teknologi informasi dewasa ini, kebutuhan akan informasi yang akurat sangat dibutuhkan dalam kehidupan sehari-hari, sehingga informasi akan menjadi suatu elemen penting dalam perkembangan masyarakat saat ini dan waktu mendatang. Namun kebutuhan informasi yang tinggi kadang tidak diimbangi dengan penyajian informasi yang memadai, seperti dalam ruang lingkup ilmu psikologi dan dalam hal mendiagnosa suatu kondisi informasi dan pengolahan data yang akurat menjadi salah satu kendala dan hampir selalu menjadi masalah yang dikeluhkan bagi pihak praktisi. dan sering kali informasi tersebut masih harus di gali ulang dari data yang jumlahnya sangat besar [1].

Masa remaja adalah masa yang pasti dialami oleh setiap orang. Pada tahapan ini seorang remaja adalah orang yang sangat peka terhadap perubahan Yang terjadi pada dirinya secara biologis maupun dengan sesuatu yang berhubungan dengan lingkungan sekitarnya. Remaja sebagai periode badai dan tekanan, suatu masa saat ketegangan emosi meninggi akibat perubahan fisik dan kelenjar. Meningginya emosi disebabkan remaja berada dibawah tekanan social, dan selama masa kanakkanak, ia kurang mempersiapkan diri untuk menghadapi keadaan itu. Sehingga mereka mengalami ketidakstabilan emosi sebagai dampak dari penyesuaian diri terhadap pola perilaku dan lingkungan social yang baru [3].

Metode yang digunakan pada penelitian ini menggunakan metode Certainty Factor (Faktor Kepastian), metode ini memberikan ruang pada pakar dalam memberikan nilai keyakinan pada pengetahuan yang diungkapkan,yaitu suatu metode untuk membuktikan apakah suatu fakta itu pasti ataukah tidak pasti yang berbentuk matrik yang biasanya digunakan dalam sistem pakar[7]. Metode ini sangat cocok untuk sistem pakar yang mendiagnosis sesuatu yang belum pasti. Program aplikasi ini diharapkan dapat membantu mendiagnosa gejala awal gangguan kepribadian pada remaja. Pada penelitian ini data yang digunakan berupa: ilmu pengetahuan, fakta, dan data. Diharapkan dengan sistem ini dapat membantu masyarakat khusunya orang tua untuk memecahkan masalah yang terjadi pada remajanya. Pada kesempatan kali ini, penulis mencoba memaparkan dengan secara lebih detail tentang jenis-jenis Gangguan kepribadian pada remaja, dan gejala-gejalanya [2]. Tidak hanya itu penulis juga akan memaparkan tentang solusi untuk menangani masalah gangguan kepribadian pada remaja. Sehubungan dengan permasalahan yg telah dikemukakan di atas, penulis tertarik untuk membuat suatu aplikasi sistem pakar untuk mendiagnosa atau mendeteksi gangguan kepribadian pada remaja sebagai solusi dari masalah yang ada dengan judul "Aplikasi Sistem Pakar untuk Mendiagnosa Gangguan Kepribadian Pada Remaja dengan Menggunakan Metode Certainty Factor (CF)"'.

\subsection{Identifikasi Masalah}

Berdasarkan latar belakang masalah yang telah dikemukakan sebelumnya, maka penulis mengidentifikasikan masalah sebagai berikut:

a. Banyaknya orang tua ataupun pengajar yang kurang memahami apakah si anak memiliki gangguan kepribadian abnormal atau tidak.

b. Banyak gejala-gejala baru yang dialami oleh remaja akibat perkembangan fisik dan pola pikir baik dari pergaulan ataupun lingkungan sosial sekitar mereka.

c. Belum adanya suatu aplikasi yang berguna untuk mendiagnosa gangguan kepribadian pada remaja.

d. Belum ada penerapan metode Certainty Factor $(C F)$ pada sistem informasi untuk mendiagnosa gangguan kepribadian pada remaja. 


\subsection{Batasan Masalah}

Dari identifikasi masalah diatas, maka penulis akan membahas tentang pembuatan Aplikasi Sistem Pakar Untuk Mendiagnosa Gangguan Kepribadian pada remaja dengan menggunakan metode certainty factor. Aplikasi sistem pakar yang dibuat akan menghasilkan output berupa gangguan kepribadian pada remaja dan beberapa terapi serta solusi penangannya dalam hal ini penulis hanya mendiagnosa gejala yang ditimbulkan pada masa remaja awal yaitu di usia 15 - 17 tahun. Aplikasi yang dirancang menggunakan bahasa pemrograman PHP dan dengan database MySQL Server, serta menggunakan metode certainty factor.

\subsection{Rumusan Masalah}

Berikut rumusan masalah dalam penelitian ini yaitu:

a. Bagaimana membuat suatu aplikasi Sistem Pakar yang dapat digunakan untuk mendiagnosa apakah seorang remaja menderita gangguan kepribadian tertentu berdasarkan gejala-gejala yang dialami?

b. Bagaimana mengimplemtasikan metode certainty factor dalam mendiagnosa gangguan kepribadian pada remaja dengan menggunakan aplikasi Sistem Pakar?

\subsection{Tujuan Penelitian}

Tujuan yang ingin dicapai dari pelaksanaan dan penulisan ini adalah

a. Mempermudah remaja atau orang tua mengetahui apakah dirinya atau anaknya mengalami gangguan dalam kepribadian atau tidak berdasarkan gejala-gejala yang terjadi sehari-hari.

b. Penerapan sistem pakar untuk pengambilan keputusan yaitu solusi dan beberapa terapi yang dapat di lakukan oleh masyarakat khususnya orang tua atau remaja itu sendiri.

\subsection{Hipotesis}

Hipotesis dari penelitian ini diharapkan dengan aplikasi system pakar Mendiagnosa Gangguan Kepribadian Pada Remaja dengan Menggunakan Metode Certainty Factor (CF) ini dapat digunakan para orang tua untuk mengetahui apakah anak mereka memiliki gangguan kepribadian.

\section{METODE PENELITIAN}

Analisa Kebutuhan Tahap analisa kebutuhan digunakan untuk mengetahui dan menerjemahkan semua permasalahan serta kebutuhan perangkat lunak dan kebutuhan sistem yang dibangun. Oleh karena itu dalam tahapan ini dilakukan proses pengumpulan data-data untuk membangun sistem diantaranya:

a. Mengenai pembentukan database

b. Basis pengetahuan (knowledge base),

c. Pembentukan rule, atau kaidah dari metode yang digunakan sistem

d. Pembentukan tabel keputusan (decision table).

Dalam penelitain ini penulis membuat data sample jumlah anak yang mengalami gangguan kepribadian. Data sampel diambil di Pusat Rehabilitasi Madani Mental Health care Jakarta Timur pada bulan agustus 2016, dan data sample yang didapatkan sebanyak 33 histori remaja yang mengalami ganggguan kepribadian. 
Tabel 1. Data Sampel Jumlah remaja yang mengalami Gangguan kepribadian

\begin{tabular}{|l|c|c|c|c|c|}
\hline \multicolumn{1}{|c|}{$\begin{array}{c}\text { Latar belakang } \\
\text { Gangguan }\end{array}$} & Umur & \multicolumn{5}{c|}{ Jenis Gangguan Kepribadian } \\
\cline { 3 - 6 } & penanganan & Paranoid & Skizoid & Skizotipe & Skizofrenia \\
\hline Gangguan Murni & 1-2 bulan & 2 & 5 & 3 & 9 \\
\hline $\begin{array}{l}\text { Gangguan efek dari } \\
\text { psikotropika }\end{array}$ & 3-6 bulan & 5 & 2 & 0 & 7 \\
\hline \multicolumn{2}{|c|}{ Jumlah } & 7 & 7 & 3 & 16 \\
\hline \multicolumn{2}{|c|}{ Total } & \multicolumn{5}{|c|}{33} \\
\hline
\end{tabular}

Langkah pertama dalam mengembangkan sistem pakar adalah mengidentifikasi permasalahan yang akan di kaji, dalam hal ini mengidentifikasi permasalahan yang akan dibuat terlebih dahulu, adapun masalah-masalah yang diambil dalam dalam pembuatan sistem pakar ini adalah gejala-gejala yang terjadi atau dialami oleh seorang remaja serta diagnosa gangguan kepribadian remaja yang dialami. Dalam hal ini akan dijelaskan mengenai beberapa definisi tentang gangguan kepribadian remaja, penyebab, gejala, serta solusi terapi yang diberikan untuk remaja. Pada sistem pakar untuk mendiagnosa gangguan kepribadian remaja ini sistem yang dibuat terstruktur dengan basis pengetahuan yang dinamis[4]. Pengetahuan yang ada pada sistem pakar dapat bertambah, sehingga harus bisa ditambah maupun dihapus tanpa harus mengubah isi program secara keseluruhan. Dalam hal ini masalah yang diperlukan dalam sistem pakar ini yaitu:

1) Data- data mengenai macam-macam gangguan kepribadian remaja

2) Gejala-gejala tentang gangguan kepribadian remaja

3) Nilai kepercayaan (Measure Believe), dan ketidakpercayaan (Measure Disbelieve).

4) Solusi terapi yang dilakukan, beserta data lain untuk mendukung sistem aplikasi pakar untuk mengidentifikasi gangguan kepribadian remaja.

\subsection{Teknik Analisis}

\subsubsection{Menentukan Nilai MB dan MD}

Certainty factor, harus melalui perhitungan nilai measure of beliefe (MB) dan measure of disbeliefe (MD). Nilai MB dan MD ada pada masing-masing gejala dan kemudian dihitung berdasarkan gejala yang dipilih oleh user nantinya. Nilai MB dan MD untuk seluruh gejela yang ada pada penelitian ini ditentukan oleh pakar gangguan kepribadian dan mental. Untuk menentukan nila MB dan MD tersebut, maka perlu rentang nilai. Semakin tinggi nilai MB maka, nilai kepercayaan atau kepastian gejala yang didapat menyebab gangguan kepribadian remaja, dan semakin tinggi nilai MD maka nilai kepastian atau ketidakpercayaan semakin tinggi. Sebaliknya semakin rendah nilai MB, maka nilai kepercayaan gejala yang diperoleh semakin kecil dan semakin rendah nilai MD maka nilai ketidakpastian atau ketidakpercayaan semakin rendah. Berikut rentang nilai dalam menentukan nilai MB dan MD [11].

Tabel 2. Penentuan Nilai MB dan MD

\begin{tabular}{|l|l|l|}
\hline NO & KETERANGAN & NILAI MB dan MD \\
\hline 1 & Tidak Tahu / Tidak Ada & $0,1-0,2$ \\
\hline 2 & Mungkin & $0,3-0,4$ \\
\hline 3 & Kemungkinan Besar & $0,5-0,6$ \\
\hline 4 & Hampir Pasti & $0,7-0,8$ \\
\hline 5 & Pasti & $0,9-1$ \\
\hline
\end{tabular}




\subsubsection{Pembentukan Tabel Keputusan (Decision Table) Penyakit dan Gejala}

Dari data penyakit gangguan kepribadian remaja dan gejala yang ada, dapat disingkat informasinya menjadi tabel keputusan (decision Table) yang isinya relasi atau hubungan antara penyakit dan gejalanya. Berikut ini Tabel Rincian Penyakit dan Gejala-gejala yang terjadi dan Tabel Keputusan tentang gangguan kepribadian remaja yang dapat dilihat pada Tabel 3 dibawah ini:

Tabel 3. Rincian Penyakit Gangguan Kepribadian

\begin{tabular}{|c|l|}
\hline KODE & \multicolumn{1}{|c|}{ NAMA PENYAKIT } \\
\hline P001 & Gangguan Kepribadian Paranoid \\
\hline P002 & Gangguan Kepribadian Skizoid \\
\hline P003 & Gangguan kepribadian Skizotipe \\
\hline P004 & Skizofrenia \\
\hline
\end{tabular}

Tabel 3 diatas menjelaskan tentang rincian penyakit gangguan Kepribadian, yang terdiri dari 4 jenis gangguan Kepribadian diantaranya Paranoid, Skizoid, Skizotipe, Skizofrenia. Data diperoleh dari hasil studi literatur dan wawancara serta observasi langsung. Dengan kode penyakit P001 sampai P004.

\subsubsection{Penentuan nilai bobot dari setiap masing- masing gejala}

Tabel 4. Bobot Nilai MB dan MD Gangguan Paranoid

\begin{tabular}{|c|l|c|c|}
\hline \multicolumn{4}{|c|}{ Paranoid } \\
\hline Kode Gejala & \multicolumn{1}{|c|}{ Nama Gejala } & MB & MD \\
\hline G001 & Serba curiga & 0,99 & 0,01 \\
\hline G002 & Hipersensitif atau sangat perasa & 0,99 & 0,01 \\
\hline G003 & Kaku & 0,99 & 0,02 \\
\hline G004 & Mudah iri & 0,8 & 0,01 \\
\hline G005 & Sangat egois & 0,87 & 0,05 \\
\hline G006 & Argumentatif atau suka menentang & 0,95 & 0,01 \\
\hline G007 & Suka Menyalahkan orang lain & 0,99 & 0,03 \\
\hline \multirow{2}{*}{ G008 } & Suka menuduh orang lain jahat dan & & 0,02 \\
& menyimpan rasa permusuhan & 0.98 & \\
\hline
\end{tabular}

Tabel 4 diatas menjelaskan tentang hasil pembobotan nilai MB dan MD gangguan kepribadian Paranoid dari gejala-gejala yang ada. Yang bersumberr dari pakar atau psikolog.

Tabel 5. Rule Tingkatan Nilai Gangguan

\begin{tabular}{|c|c|c|}
\hline Kode Aturan & Aturan & Range \\
\hline AT1 & Sangat Tinggi & $>0,83$ \\
\hline AT2 & Tinggi & $0,82-0,61$ \\
\hline AT3 & Rata-Rata & $0,6-0,33$ \\
\hline AT4 & Rendah & $<0,33$ \\
\hline
\end{tabular}


Tabel 5 diatas adalah aturan rule yang dipakai untuk mengklasifikasikan nilai dari hasil perhitungan CF Akhir.

\subsection{Pengolahan Data}

Pengolahan data merupakan suatu proses dalam ringkasan atau angka ringkasan dengan menggunakan cara-cara atau rumus-rumus tertentu. Pengolahan data bertujuan mengubah data mentah dari hasil pengukuran menjadi data yang lebih halus sehingga memberikan arah untuk pengkajian lebih lanjut. Pengolahan data untuk analisis data dilakukan dengan tehnik analisis deskriptif kuantitatif[9]. Data yang diperoleh dalam penelitian ini adalah data gejala-gejala gangguan Kepribadian remaja beserta jenis gangguan kepribadinnya dan nilai MB serta MD yang diberikan langsung oleh pakar.

\section{a. Metode Penelusuran Gejala dalam Penalaran}

Metode penalaran gejala yang digunakan dalam sistem ini adalah penalaran maju (Forward Chaining) yaitu dimulai dari sekumpulan fakta - fakta tentang suatu gejala yang diberkan oleh user sebagai masukan sistem, selanjutnya dilakukan pelacakan sampai tujuan akhir berupa diagnosis kemungkinan jenis gangguan yang diderita dan penjelasan tentang jenis gangguan perkembangan yang diderita serta cara penanganan atau solusi yang diberikan[15].

\section{b. Perhitungan Nilai Certainty Factor}

Dalam mengekespresikan derajat keyakinan certainty theory menggunakan nilai yang disebut certainty factor $(\mathrm{CF})$ untuk mengamsumsikan derajat keyakinan seorang pakar terhadap suatu data.Certainty factor memperkenalkan konsep believel keyakinan dan disbelieve/ ketidak yakinan. Konsep ini kemudian di formulasikan dalam rumusan dasar sebagai berikut:

$\mathrm{CF}[\mathrm{H}, \mathrm{E}]=\mathrm{MB}[\mathrm{H}, \mathrm{E}]-\mathrm{MD}[\mathrm{H}, \mathrm{E}]$

Keterangan :

CF $(\mathrm{H}, \mathrm{E})$ : Certainty Factor dari hipotesis $\mathrm{H}$ yang dipengaruhi oleh gejala (Evidance) E. Besar CF berkisar antara -1 sampai dengan 1. Nilai -1 menunjukan ketidakpercayaan mutlak sedangkan nilai 1 menunjukan kepercayaan mutlak.

MB (H,E) : Ukuran kenaikan kepercayaan (measure of increased believe) terhadap hipotesis $\mathrm{H}$ yang dipengaruhi oleh gejala.

$\mathrm{MD}(\mathrm{H}, \mathrm{E})$ : kenaikan ketidakpercayaan (measure of increas disbelieve) terhadap hipotesis $\mathrm{H}$ yang dipengaruhi oleh gejala $\mathrm{E}$.

E : Evidence (peristiwa atau fakta).

$\mathrm{H} \quad$ : Hipotesis (Dugaan).

Setelah MB dan MD dari eviden e1 dan e2 diketahui maka tinggal memasukannya ke rumus dasar, yaitu

$$
\mathrm{CF}\left[\mathrm{h}, \mathrm{e} 1^{\wedge} \mathrm{e} 2\right]=\mathrm{MB}\left[\mathrm{h}, \mathrm{e} 1^{\wedge} \mathrm{e} 2\right]-\mathrm{MD}\left[\mathrm{h}, \mathrm{e} 1^{\wedge} \mathrm{e} 2\right]
$$

\section{$\mathrm{CF}[\mathrm{H}, \mathrm{E}] \mathbf{1}=\mathrm{CF}[\mathrm{H}] \mathrm{xCF}[\mathrm{E}]$}

Certainty Factor untuk kaidah dengan kesimpulan yang serupa (similary conclude rules):

$$
\begin{aligned}
& \text { CFcombine1,2=CF[H,E]1+CF[H,E } 2 \\
& \text { CFcombineCF[H,E]old,3=CF[H,E]old }+ \text { CF[H,E }] 3 \text { x[1 - CF[H,E]old }]
\end{aligned}
$$

Dimana penjelasan dari persamaan (2) adalah sebagai berikut:

CFcombine1,2 :

Faktor kepastian kombinasi dari $\mathrm{CF}[\mathrm{H}, \mathrm{E}] 1$ dan $\mathrm{CF}[\mathrm{H}, \mathrm{E}] 2$. 
$\mathrm{CF}[\mathrm{H}, \mathrm{E}] 1 \quad$ :

Ukuran kepercayaan Hipotesis H, Jika Diberikan evidence E1 pertama (antara 0 dan 1)

$\mathrm{CF}[\mathrm{H}, \mathrm{E}] 2$

Ukuran kepercayaan Hipotesis H, Jika Diberikan evidence E2 pertama (antara 0 dan 1)

CFcombine $\mathrm{CF}[\mathrm{H}, \mathrm{E}]$ old, 3 :

Faktor kepastian kombinasi pararel dari $\mathrm{CF}[\mathrm{H}, \mathrm{E}] 2$ dan $\mathrm{CF}[\mathrm{H}, \mathrm{E}]$ old.

Dengan Metode dan rumus diatas didapatkan perhitungan untuk nilai Certainty Factor dari masing-masing penyakit sebagai berikut:

Tabel 6. Perhitungan Gangguan kepribadian Paranoid

\begin{tabular}{|c|c|c|c|}
\hline \multicolumn{3}{|c|}{ Paranoid } \\
\hline Kode_Gejala & MB & MD & $\begin{array}{c}\text { CF - } \\
\text { MB [H,E] - MD [H,E] }\end{array}$ \\
\hline G001 & 0,99 & 0,01 & 0,98 \\
\hline G002 & 0,99 & 0,01 & 0,98 \\
\hline G003 & 0,99 & 0,02 & 0,97 \\
\hline G004 & 0,8 & 0,01 & 0,79 \\
\hline G005 & 0,87 & 0,05 & 0,82 \\
\hline G006 & 0,95 & 0,01 & 0,94 \\
\hline G007 & 0,99 & 0,03 & 0,96 \\
\hline G008 & 0.98 & 0,02 & 0,96 \\
\hline
\end{tabular}

Tabel 6 diatas adalah Perhitungan Nilai CF Pakar Gangguan Kepribadian Paranoid akhir hasil dari Nilai MB dikurangi Nilai MD.

Tabel 7. Perhitungan Gangguan Skidoid

\begin{tabular}{|c|c|c|c|}
\hline \multicolumn{4}{|c|}{ Skizoid } \\
\hline Kode_Gejala & MB & MD & $\begin{array}{r}\text { CF - } \\
\text { MB [H,E] - MD [H,E] }\end{array}$ \\
\hline G009 & 0,99 & 0,01 & 0,98 \\
\hline G010 & 0.87 & 0,05 & 0,82 \\
\hline G011 & 0,97 & 0,01 & 0,96 \\
\hline G012 & 0,95 & 0,01 & 0,94 \\
\hline
\end{tabular}

Tabel 7 diatas adalah Perhitungan Nilai CF Pakar Gangguan Kepribadian Skizoid akhir hasil dari Nilai MB dikurangi Nilai MD.

Tabel 8. Perhitungan Gangguan Skizotipe

\begin{tabular}{|c|c|c|c|}
\hline \multicolumn{4}{|c|}{ Skizotipe } \\
\hline Kode_Gejala & MB & MD & $\begin{array}{c}\text { CF - } \\
\text { MB [H,E] - MD [H,E] }\end{array}$ \\
\hline G002 & 0,99 & 0,01 & 0,98 \\
\hline G012 & 0,95 & 0,01 & 0,94 \\
\hline G013 & 0,99 & 0,02 & 0,97 \\
\hline G014 & 0.98 & 0,02 & 0,96 \\
\hline G015 & 0,99 & 0,01 & 0,98 \\
\hline
\end{tabular}


Tabel 8 diatas adalah Perhitungan Nilai CF Pakar Gangguan Kepribadian Skizotipe akhir hasil dari Nilai MB dikurangi Nilai MD.

\section{Perhitungan nilai CF dari pengguna (user)}

Tabel 9. Klasifikasi Nilai CF dari User

\begin{tabular}{|c|c|c|}
\hline No & Jawaban & Nilai CF \\
\hline 1 & Tidak & 0 \\
\hline 2 & Tidak Tau & 0,2 \\
\hline 3 & Kadang & 0,4 \\
\hline 4 & Cukup Sering & 0,6 \\
\hline 5 & Sering & 0,8 \\
\hline 6 & Sangat sering & 1 \\
\hline
\end{tabular}

Tabel 9 diatas adalah Tingakatan dan Klasifikasi penilaian untuk nilai CF user .

\section{Studi Kasus}

Nama Pasien : Fatan

Umur : 15 Tahun

Latar Belakang : Anak ke-2 dari 4 bersaudara

Keluhan user : Perubahan terlihat 6 bulan kebelakang. Memasuki tahun ajaran baru di sekolah menengah Atas. Keterangan dari wali kelas bahwa si anak pendiam dan cenderung menghindari teman sekelasnya. Sering diejek karena pendiam. Menjadi anak yang serba curiga dan berfikir negatif terhadap teman sebayanya. Suka menyendiri dikamar berbicara didepan kaca sambil bertakhayul terkadang gelisah dan berhalusinasi dengan berandai bahwa dirinya orang besar yang hebat.

2. Penentuan nilai CF dari pengguna yang berdasarkan pilihan jawaban pengguna yaitu sebagai berikut:

Tabel 10. Hasil Nilai CF dari User

\begin{tabular}{|c|c|c|c|c|c|c|c|}
\hline \multirow[b]{2}{*}{ Gejala } & \multicolumn{6}{|c|}{ Klasifikasi Nilai CF } & \multirow{2}{*}{$\begin{array}{c}\text { Nilai } \\
\text { CF } \\
\text { User }\end{array}$} \\
\hline & Tiaks & $\begin{array}{l}\text { Tilak } \\
\text { Tath }\end{array}$ & Koing & $\begin{array}{l}\text { Colup } \\
\text { sering }\end{array}$ & Sering & $\begin{array}{l}\text { Sangat } \\
\text { Sering }\end{array}$ & \\
\hline Serba curiga & & & & $\checkmark$ & & & 0,6 \\
\hline $\begin{array}{l}\text { Suka menuduh orang lain } \\
\text { jahat dan menyimpan rasa } \\
\text { permusuhan }\end{array}$ & & & $\sqrt{ }$ & & & & 0,4 \\
\hline $\begin{array}{l}\text { Tidak mampu atau } \\
\text { menarik diri dari menarik } \\
\text { lingkungan sosial }\end{array}$ & & & & & $\sqrt{ }$ & & 0,8 \\
\hline
\end{tabular}

Tabel 10 diatas adalah pembobotan nilai CF user dinilai dari klasifikasi penilaian ditiap gejala yang di nilai oleh user. 


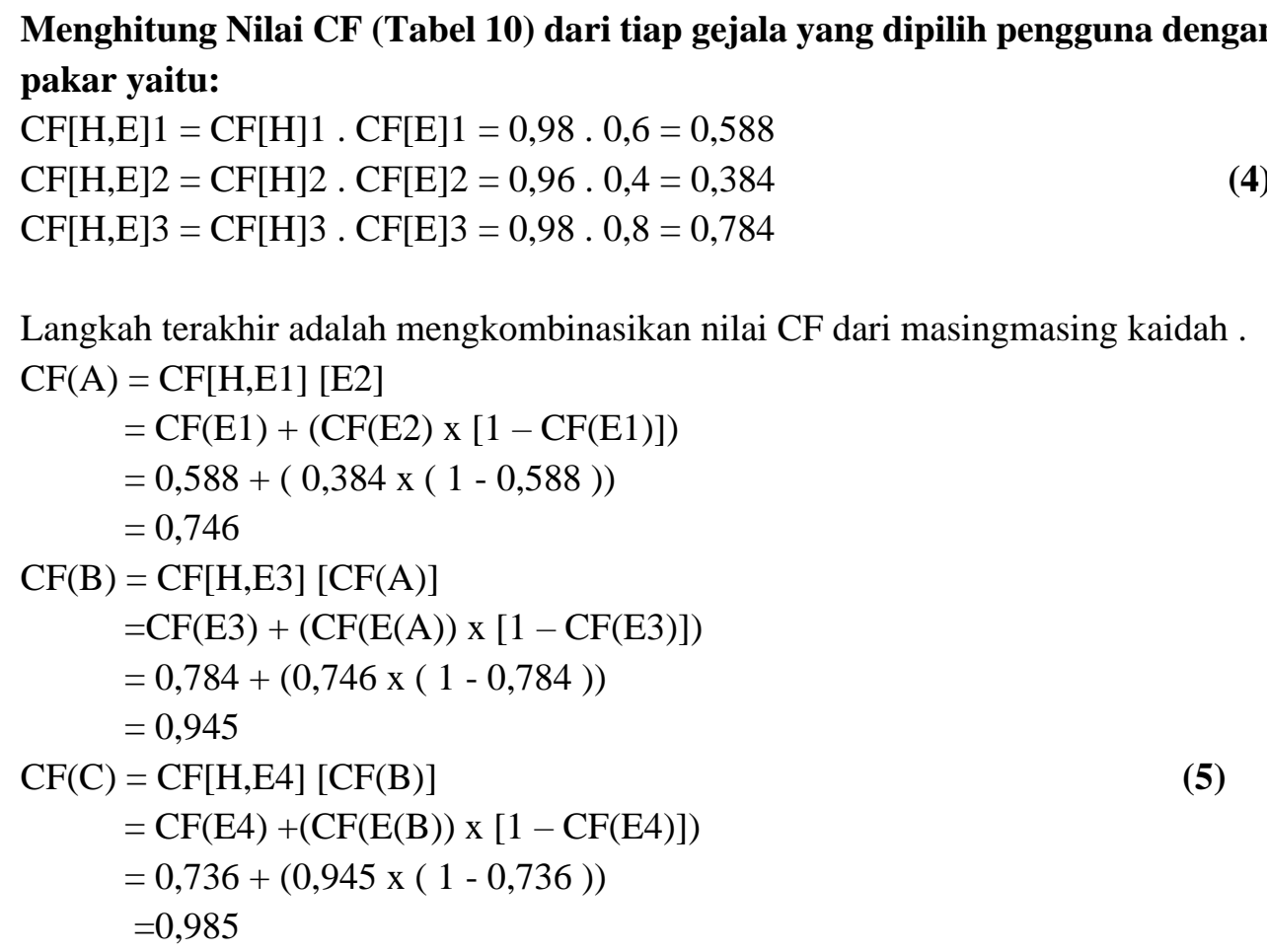

Dari perhitungan secara manual diatas, diperoleh nilai CF dari masukan gejala yang merujuk ke gangguan kepribadian Skizofrenia adalah 0,999. menurut Tabel 10 hal ini menunjukan bahwa penderita mengalami tingkat gangguan kepribadian Skizofrenia Sangat Tinggi. Dengan demikian kondisi si Pasien sudah sangat butuh pembinaan serta pengobatan. Dengan program yang ada di Madani Mental Health Care penderita Skrizofrenia dijalankan melalui beberapa tahap, dimulai dengan tahap pertama yaitu:

1. Tahap pertama, Terapi Stabilisasi/Detoksifikasi.

2. Tahap kedua, Rehabilitasi dalam jangka waktu 3 bulan dan dapat diperpanjang sesuai perkembangan.

3. Program lanjutan Day Care dan kemandirian selama 3 bulan.

\section{HASIL DAN PEMBAHASAN}

\subsection{Perancangan Sistem}

Setelah beberapa tahapan dalam pengembangan sistem yang dilakukan, maka tahapan selanjutnya adalah perancangan sistem. Tahapan ini merupakan tahapan yang sangat penting, karena dengan dilakukannya tahapan ini maka kita akan mengetahui sejauh mana sistem dapat berjalan sesuai dengan tujuan dari pembuatan sistem pakar ini yang sesuai dengan keinginan user atau admin. Dalam perancangan sistem terdiri dari 2 sudut pandang yaitu sudut pandang user atau admin dan sudut pandang logical. Sudut pandang user atau admin terdiri dari use case diagram dan activity diagram, sedangkan sudut pandang logical terdiri class diagram dan sequence[12]. 


\section{KILAT}

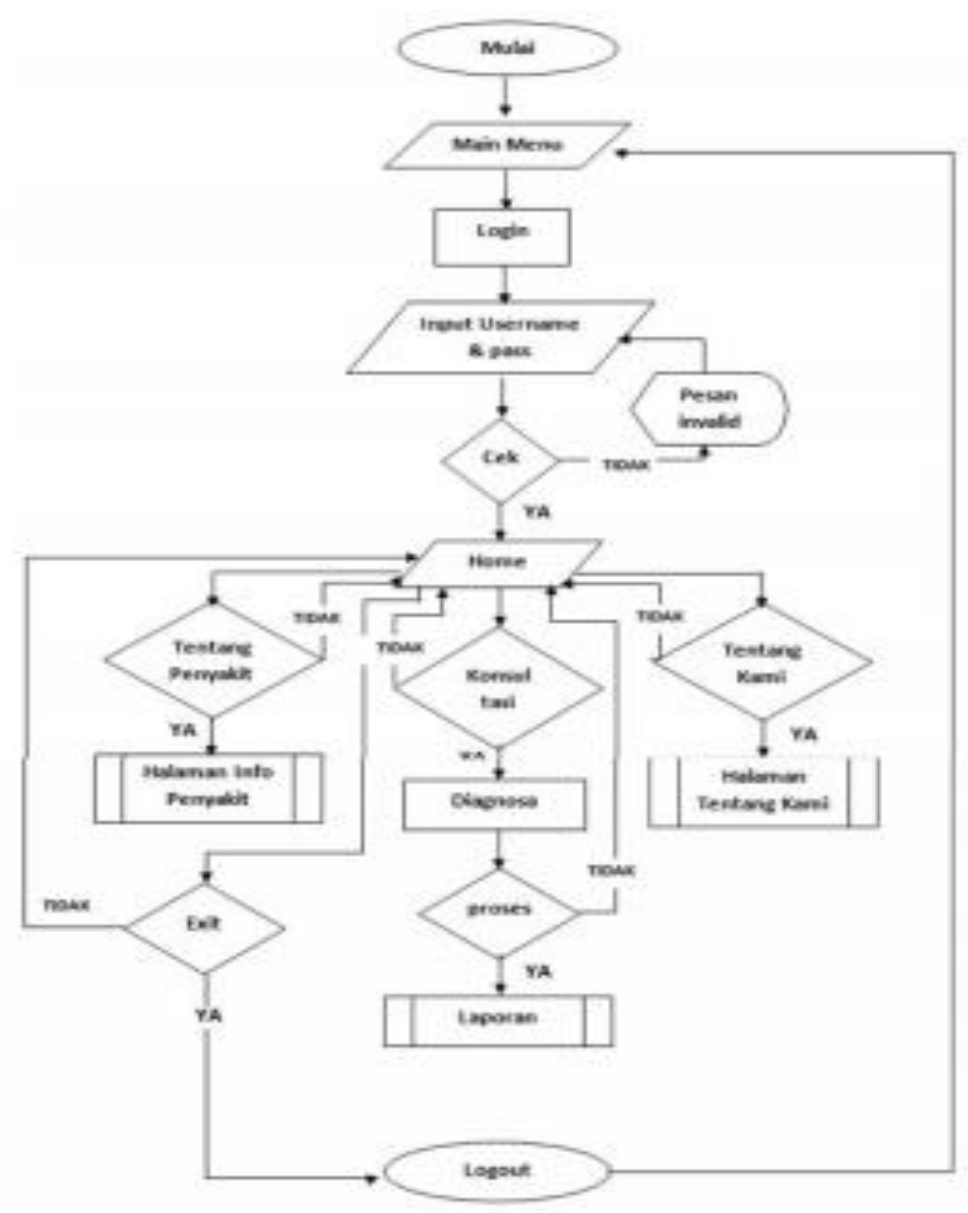

Gambar 1. Flowchart Sistem Pakar Diagnosa Gangguan Kepribadian

\subsection{Rancangan Halaman Admin}

a. Login Admin Rancangan halaman login merupakan halaman yang dipergunakan oleh seorang admin untuk dapat mengakses aplikasi ini dengan melakukan login terlebih dahulu sebagai admin atau pakar, Rancangan 98 tampilan halaman login ditunjukan pada gambar dibawah ini:

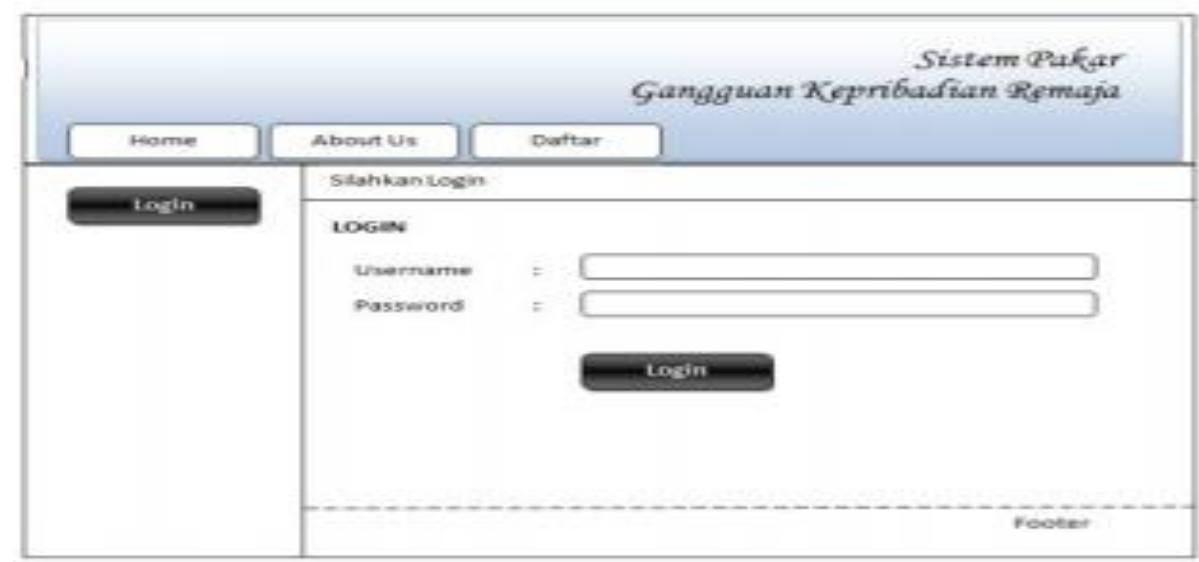

Gambar 2. Rancangan Halaman Login admin 


\section{b. Rancangan Halaman Data Master Gangguan}

Pada halaman ini merupakan halaman yang digunakan admin atau pakar untuk melakukan menajemen data pakar. Admin dapat menambah data, mengubah serta menghapus data gangguan Kepribadian Seperti gambar dibawah ini.

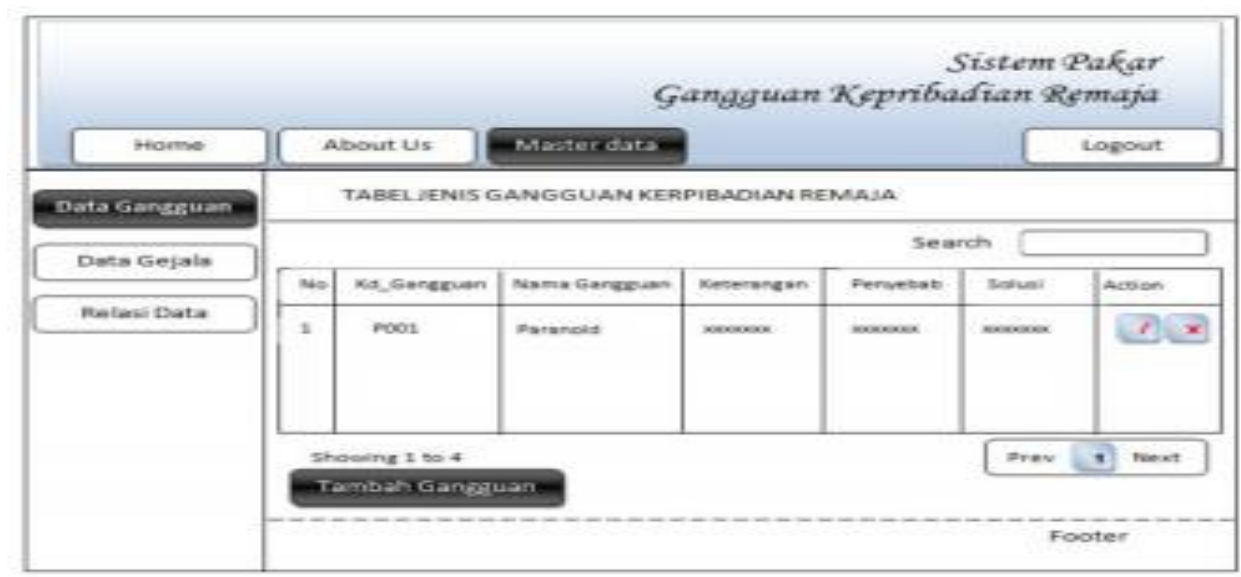

Gambar 3. Rancangan Halaman Data Master Gangguan

\subsection{PEMBAHASAN}

\subsubsection{Implementasi Antarmuka}

Pada tahap ini dilakukan penerapan hasil perancangan antarmuka ke dalam sistem yang dibangun dengan menggunakan perangkat lunak yang telah dipaparkan pada sub bab implmentasi perangkat lunak. Untuk mengetahui lebih jelas tentang proses yang ada di dalam sistem beserta hasil implementasinya dapat dilihat seperti dibawah ini:

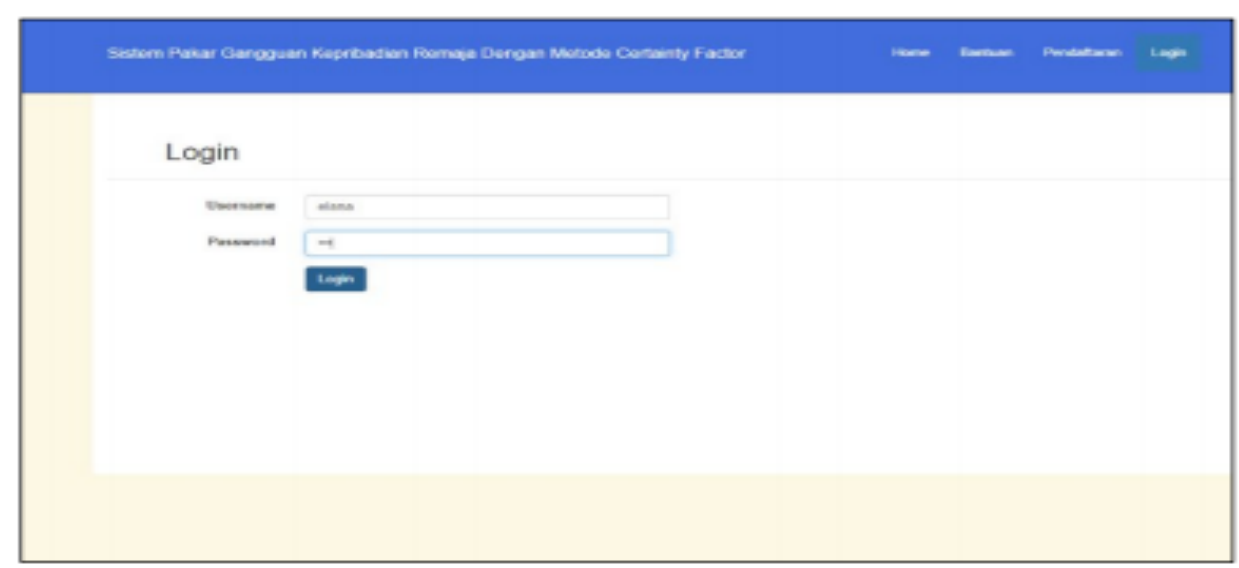

Gambar 4. hasil rancangan Login User 


\section{KILAT}

Vol. 8, No. 2, Oktober 2019, P-ISSN 2089-1245, E-ISSN 2655-4925

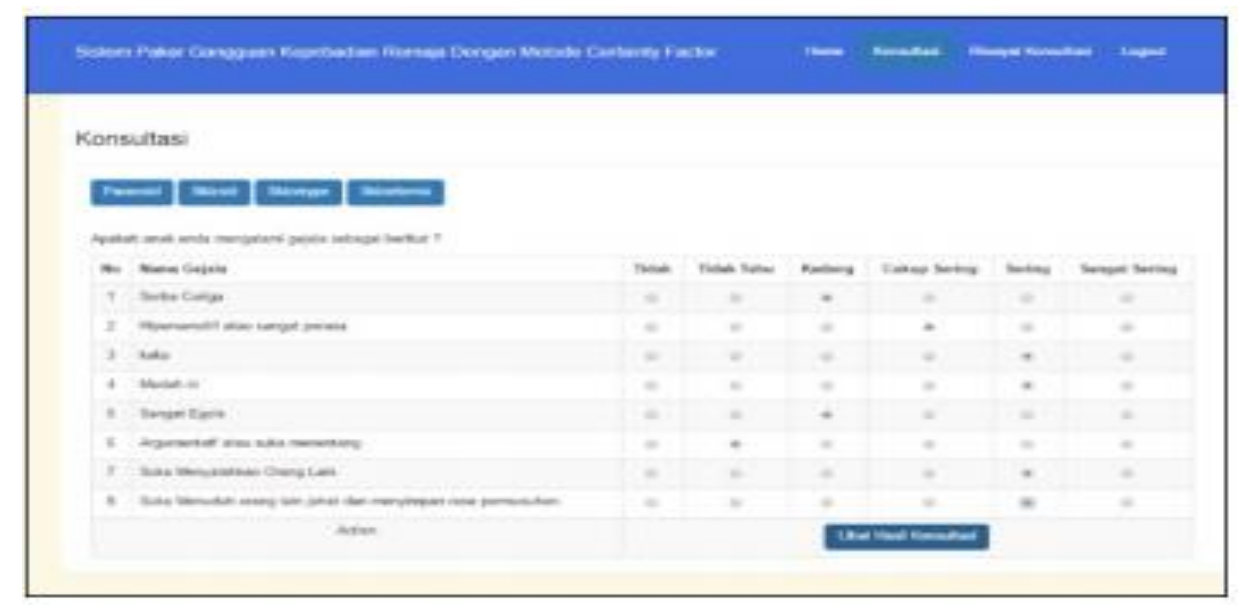

Gambar 5. menuKonsultasi

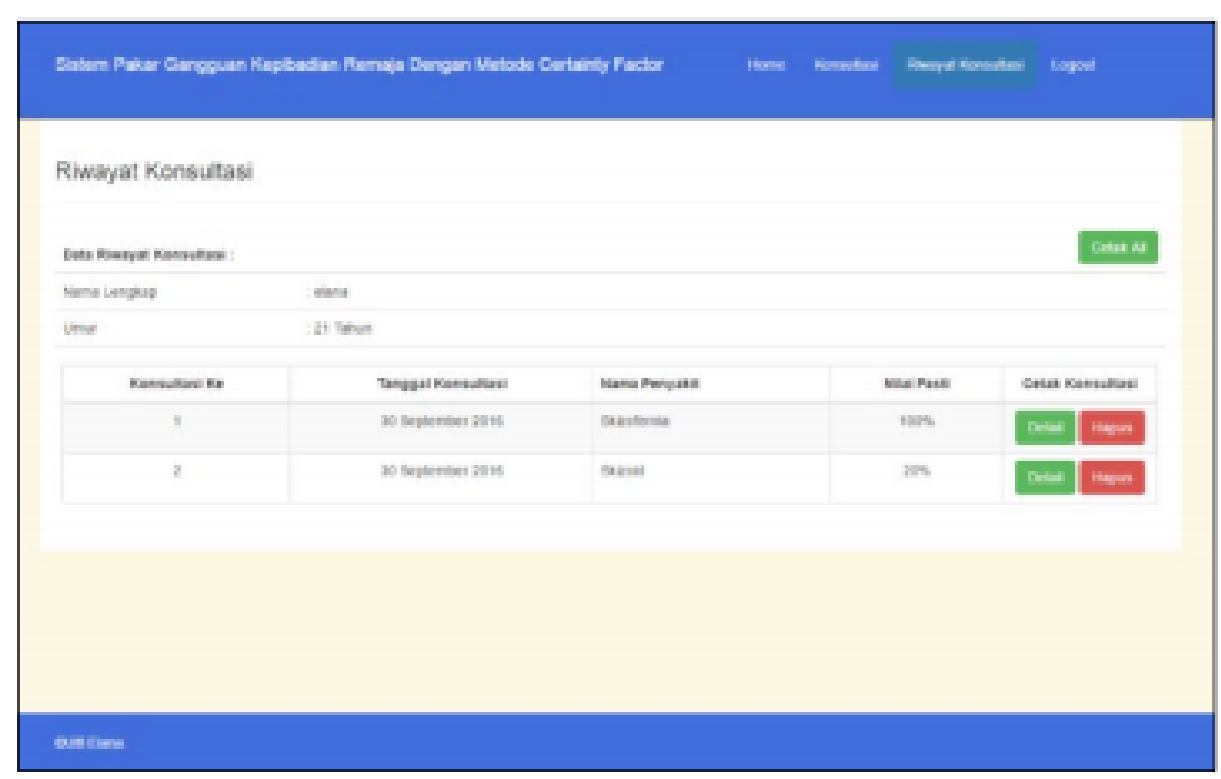

Gambar 6. Menu Riwayat Konsltasi

\section{KESIMPULAN DAN SARAN}

Berdasarkan pembahasan mengenai sistem pakar dalam mendiagnosa masalah gangguan Kepribadian remaja, maka kesimpulan yang dapat diambil adalah sebagai berikut:

\subsection{Kesimpulan}

a. Aplikasi sistem pakar ini dibuat dengan menggunakan bahasa pemroggraman PHP, perancangan database menggunakan MySQL dan pengujian menerapkan metode Black box. aplikasi ini dibuat untuk mendiagnosa gangguan kepribadian yang terjadi pada remaja dengan mengetahui hasil dari perhitungan nilai gejala-gejala yang sudah dipaparkan dalam sistem pakar ini.

b. Aplikasi sistem pakar ini menerapkan metode faktor kepercayaan (certainty factor) untuk menghitung nilai kepastian hasil diagnosa yang dilakukan sistem. Penerapan metode CF ini membutuhkan nilai dari seorang pakar untuk setiap gejala yang ada, karena hasil dari 
perhitungan nilai gejala sistem pakar ini berbentuk nilai persentase kemungkinan si remaja menderita gangguan kepribadian. Dari hasil diagnosa sistem pakar ini pula akan menghasilkan sebuah solusi bagi penanganan awal gangguan si remaja tersebut. Yang di harapkan mampu memberikan informasi solusi bagi pengguna dalam mendiagnosa gangguan kepribadian remaja berdasarkan gejala - gejala yang dialami oleh remaja tersebut.

\subsection{Saran}

Saran yang diberikan oleh penulis berkaitan dengan pembuatan sistem pakar ini adalah:

a. Aplikasi sistem pakar untuk mendiagnosa gangguan kepribadian remaja ini masih perlu dikembangkan dalam metode penelitian dengan bekerja sama dengan dokter atau psikolog untuk mendapatkan informasi sistem pakar yang lebih kompleks lagi.

b. Metode sistem pakar yang digunakan tidak harus menggunakan metode certainty factor dengan memberikan nilai kepastian, hal ini di tujukan untuk masyarakat dan orang tua apabila melakukan konsultasi mendapatkan nilai akurasinya.

c. Sistem pakar ini harus selalu mencari informasi mengenai gangguan kepribadian remaja yang didasari dari gejala-gejela baru yang terus berkembang. Agar data mengenai jenis dan gangguan kepribadian remaja dengan metode certainty factor ini dapat terus diperbarui, untuk memudahkan orang tua dan masyarakat dalam mencari informasi tentang gangguan kepribadian tersebut.

d. Sistem pakar ini akan sangat berguna apabila dapat diunduh oleh masyarakat luas melaluin Play store dan dapat pula diaplikasikan melalui smartphone.

\section{DAFTAR PUSTAKA}

[1] Arbi, Armawati, Dr. (2012). Psikologi Komunikasi Dan Tabligh. Jakarta: Penerbit AMZAH.

[2] Fitriyah, Lailatul \& Jauhar, Mohammad. ( 2014 ). Pengantar Psikologi Klinis. Jakarta: penerbit Prestasi Pustaka Jakarta.

[4] Hartati, S. \& Iswanti, H (2008). Sistem Pakar dan Pengembangannya. Yogyakarta: Graha Ilmu

[5] Jogiyanto, H.M, (2005). Analisis Dan Desain Sistem. Yogyakarta: Penerbi: Andi Offset.

[6] Kusrini. 2006. Sistem Pakar Teori dan Aplikasi, Yogyakarta: Penerbit Andi.

[7] Marpaung, P., B (2015). Sistem Pakar untuk Mendiagnosa Penyakit Atherosklerosis dengan menggunakan Metode Certainty Factor. ISSN: 2339-210X. Medan: Majalah Ilmiah Informasi dan Teknologi Ilmiah (INTI), Volume: V, Nomor: 3, Februari 2015.

[8] Nugroho, B. (2005). Rational Rose Untuk Pemodelan Berbasis Objek. Bandung: Informatika.

[9] Nugroho, B. (2005). Database Relasional dengan MySQL. Yogyakarta: Andi Offset.

[10] Nugroho, B. (2008). Membuat Aplikasi Sistem Pakar dengan PHP dan Editor Dreamweaver. Yogyakarta: Gava Media

[11] Oktavia, Nur. (2015). Rancang Bangun Sistem Pakar Untuk Mendiagnosis gangguan kepribadian histerik menggunakan Metode Certainty Factor. ISSN: 2301-9425. Jombang: Sistem Informasi, Fakultas Teknik, Universitas Pesantren tinggi Darul `ulum. Volume: 1, Nomor: 1, Januari 2015140

[12] Oktavian, P.D. (2010).Menjadi Programer Jempolan Menggunakan PHP. Yogyakarta: MediaKom.

[13] Semiun, Yustinus. (2013). Teori-teori Kepribadian. Yogyakarta: Penerbit Kanisius. 


\section{KILAT}

Vol. 8, No. 2, Oktober 2019, P-ISSN 2089-1245, E-ISSN 2655-4925

[14] Suciati, (2009). Psikologi Komunikasi Sebuah Tinjauan Teoritis dan Perspektif Islam. Yogyakarta: Penerbit Buku Litera.

[15] Taufik, Ichsan. (2014). Aplikasi Diagnosa gangguan Kepribadian. ISSN: 1979- 8911. Bandung: Teknik Informatika, Fakultas Sains dan Teknologi, Universitas Islam Negeri Sunan Gunung Djati. Volume: VIII, Nomor: 2, Agustus 2014

[16] Wahab, Rohmalina, Dra. (2008). Psikologi Belajar.Ja karta: Penerbit PT. Rajagrafindo Persada. 